\title{
The Spalling of Geopolymer High Strength Concrete Wall Panels and Cylinders Under Hydrocarbon Fire
}

\author{
Ahmad Zurisman Mohd $\mathrm{Ali}^{1, \mathrm{a}}$ and Jay Sanjayan ${ }^{2}$ \\ ${ }^{1}$ Department of Structural and Materials, Universiti Tun Hussein Onn Malaysia, 86400 Parit Raja, Johor, Malaysia \\ ${ }^{2}$ Centre for Sustainable Infrastructures, Swinburne University of Technology, Australia
}

\begin{abstract}
Concrete structures were designed to withstand various types of environment conditions from mild to very severe conditions. Fire represents one of the most severe environmental conditions to which concrete structures may be subjected especially in close conduct structure like tunnel. This paper focuses on the spalling of geopolymer high strength concrete exposed to hydrocarbon fire for minimum 2 hours. From the fire test, geopolymer concrete can be classified as a good fire resistance construction materials based on spalling performance of high strength concrete when exposed to hydrocarbon fire. A maximum of $1 \%$ (excluding water moisture loss) of spalling recorded for high strength geopolymer concrete wall panel. No explosive spallings were observed for high strength geopolymer concrete.
\end{abstract}

\section{Introduction}

The needs for concrete structures to withstand fire condition are far more demanding nowadays with numbers of concrete tunnels, petro-chemical's plant and other mega structures are being built all around the world. For example, a fire in Channel tunnel $(35 \mathrm{~km}$ railroad tunnel connecting England and France) in 1996 caused severe damage to concrete tunnel rings owing to the spalling of concrete and resulted in six-month closure for repairs costing US\$1.5 million per day [1]. On 24 March 1999, a cargo truck carrying margarine and flour in the Mont Blanc tunnel connecting France and Italy caught fire and stopped at Kilometre 6.7 causing 39 human deaths and severely damaging $900 \mathrm{~m}$ long tunnel roof due to spalling [2]. A fire occurred in the Great Belt tunnel in Denmark in 1995 also causing severe spalling of concrete tunnel rings [3].Due to high usage of concrete as construction material, it is important to develop high fire resistance concrete that can sustain structural integrity when exposed to fire event. Geopolymer concrete known as very high fire resistance material due to its ceramic-like properties [4]. Lyon et al. [5] reported that geopolymer composites is ideally suited for construction, transportation and infrastructure where fire endurance is part of needed requirement . Low cost geopolymer resins can be produced by activation of fly ash. Geopolymer concrete is produced by combining these resins with coarse and fine aggregates using the conventional concrete technology methods. Since fly ash is an industrial by-product from coal power stations (largely wasted by dumping in landfills), the cost of manufacturing this concrete can be potentially lower than the conventional Portland cement based concrete. Research works reported so far in the literature indicate that geopolymers have superior fire resistance when compared to conventional concretes [6-8]. The

\footnotetext{
${ }^{\mathrm{a}}$ Corresponding author : zurisman@uthm.edu.my
} 


\section{MATEC Web of Conferences}

superior fire resistance properties are attributed to the ceramic-like properties of geopolymers, including the way it looks: smooth, glassy and shiny [9] Geopolymer concrete strength after elevated temperature exposure can increase due to further geopolymerisation [6]. However, there are strength decrease of geopolymer concrete after elevated temperature exposure especially geopolymer concrete with coarse aggregate. Thermal incompatibilities due to difference thermal expansions between aggregates and binder contributes to the decline in geopolymer concrete strength [7]. The results in this paper represent the performance of geopolymer high strength concrete panel and cylinder exposed to hydrocarbon fire exposure. The amount of spalling and residual compressive strength after fire exposures are reported in this paper.

\section{Experimental Program}

\subsection{Raw materials}

Aluminosilicate source for making geopolymer concrete in this study is fly ash. The fly ash was sourced from Gladstone power station in Queensland. Chemical composition of Gladstone fly ash is shown in Table 1. Sand for the geopolymer high strength concrete was sourced from Langwarrin quarry, Melbourne. The sand absorbed $0.3 \%$ of water. Coarse aggregate with the maximum diameter of $14 \mathrm{~mm}$ sourced from Oakland Junction, Hornsfel and supplied by Readymix ${ }^{\mathrm{TM}}$. Coarse aggregate water absorption was $0.8 \%$. Sodium silicate and sodium hydroxide were used as alkaline activator for the geopolymer high strength concrete. D grade sodium silicate was supplied by PQ Australia. Sodium hydroxide was supplied by Orica Chemical with $99 \%$ purity. Sodium hydroxide of $8.0 \mathrm{M}$ solution was made by mixing $26.2 \%$ of $\mathrm{NaOH}$ solids and $73.8 \%$ of water [10].

Table 1. Fly ash chemical compounds.

\begin{tabular}{|c|c|}
\hline Chemical Compounds & Weight (\%) \\
\hline $\mathrm{Al}_{2} \mathrm{O}_{3}$ & 25.56 \\
$\mathrm{BaO}$ & 0.09 \\
$\mathrm{CaO}$ & 4.3 \\
$\mathrm{Fe}_{2} \mathrm{O}_{3}$ & 12.48 \\
$\mathrm{~K}_{2} \mathrm{O}$ & 0.7 \\
$\mathrm{MgO}$ & 1.45 \\
$\mathrm{MnO}$ & 0.15 \\
$\mathrm{Na}_{2} \mathrm{O}$ & 0.77 \\
$\mathrm{P}_{2} \mathrm{O}_{5}$ & 0.885 \\
$\mathrm{SO}_{3}$ & 0.24 \\
$\mathrm{SiO}_{2}$ & 51.11 \\
$\mathrm{TiO}_{2}$ & 1.32 \\
$\mathrm{LOI}^{*}$ & 0.57 \\
$\mathrm{Total}$ & 99.62 \\
\hline
\end{tabular}




\subsection{Geopolymer concrete mix}

Targeted compressive strength for geopolymer high strength concrete is $50 \mathrm{MPa}$. Geopolymer concrete was made with alkaline activator to fly ash ratio of 0.5 . The $\mathrm{Na}_{2} \mathrm{SiO}_{3} / \mathrm{NaOH}$ ratio for alkaline solution was 2.5. Average compressive strength of geopolymer concrete was $64.1 \mathrm{MPa}$ and it can be classified as geopolymer high strength concrete according to EN 206:2013 [11].

\subsection{Geopolymer concrete casting}

Geopolymer concrete was casted at Commonwealth Scientific and Industrial Research Organization (CSIRO) laboratory in Highett, Australia. The geopolymer concrete mixing procedure was according to Hardjito et al. [12]. Sodium silicate and sodium hydroxide were mixed together for 10 minutes prior to concrete mixing to form an alkaline activator. Geopolymer concrete was mixed in high shear concrete mixer.. Dry components of concrete (coarse aggregates + sand) were mixed for 3 minutes. One percent of water was added into the dry mixture to make the coarse aggregates and sand in saturated surface dry condition. Fly ash was added and mixed with aggregates for further 3 minutes. Alkaline activator was then added into the mixer for further 5 minutes. The fresh geopolymer concrete had a stiff consistency and was glossy in appearance. The geopolymer concrete was then cast and compacted in $1.075 \mathrm{~m} \times 1.075 \mathrm{~m} \mathrm{x} 0.2 \mathrm{~m}$ (thickness), $150 \mathrm{~mm}$ (diameter) x $300 \mathrm{~mm}$ and $100 \mathrm{~mm}$ (diameter) x $200 \mathrm{~mm}$ moulds. The cast geopolymer concrete panels and cylinders were cured using steam curing at $60^{\circ} \mathrm{C}$ temperature for 24 hours before demoulded. Compressive strength test for geopolymer concrete was carried out at the age of 1 day, 7 days and 28 days.

\subsection{Fire testing regime}

Hydrocarbon fire temperature versus time in accordance to EN 1991-1-2 was used for exposing the specimens. Standard fire curve is commonly used for testing for fire exposures in buildings whereas the Hydrocarbon fire test is more suitable for infrastructure applications where the concrete is likely to be exposed to fire originated from hydrocarbons (eg. tunnels). Equation (1) is the hydrocarbon fire temperature [13]. The fire tests were conducted for minimum of 120 minutes.

$$
T=1080\left(1-0.325 e^{-0.167 t}-0.675 e^{-2.5 t}\right)+20
$$

where $\mathrm{T}=$ Temperature $\left({ }^{\circ} \mathrm{C}\right)$ and $\mathrm{t}=$ time (minute).

\section{Result and Discussions}

\subsection{Spalling}

Figure 1 shows the geopolymer concrete condition after exposed to hydrocarbon fire for 2 hours for panels and cylinders respectively. No explosive spalling noises were heard during the whole fire test period. After the fire test, there were some minor surface spalling was observed on 2 out of 4 geopolymer concrete panels with maximum of $4.65 \%$ concrete spalling. Geopolymer concrete cylinder did not have any spalling at all and all cylinders remained in their original shape. However, there was a loss in weight for all specimens due to loss of moisture content. Based on weight loss on unspalled panels, $3.57 \%-3.75 \%$ of moisture evaporated from the concrete panel during the fire test. Therefore, it can be estimated that less than $1 \%$ of geopolymer concrete panel spalled when exposed to hydrocarbon fire. For geopolymer concrete cylinders, since there is no any spalling observed, average of $2.86 \%$ of weight loss was purely the loss of moisture content inside the concrete. 

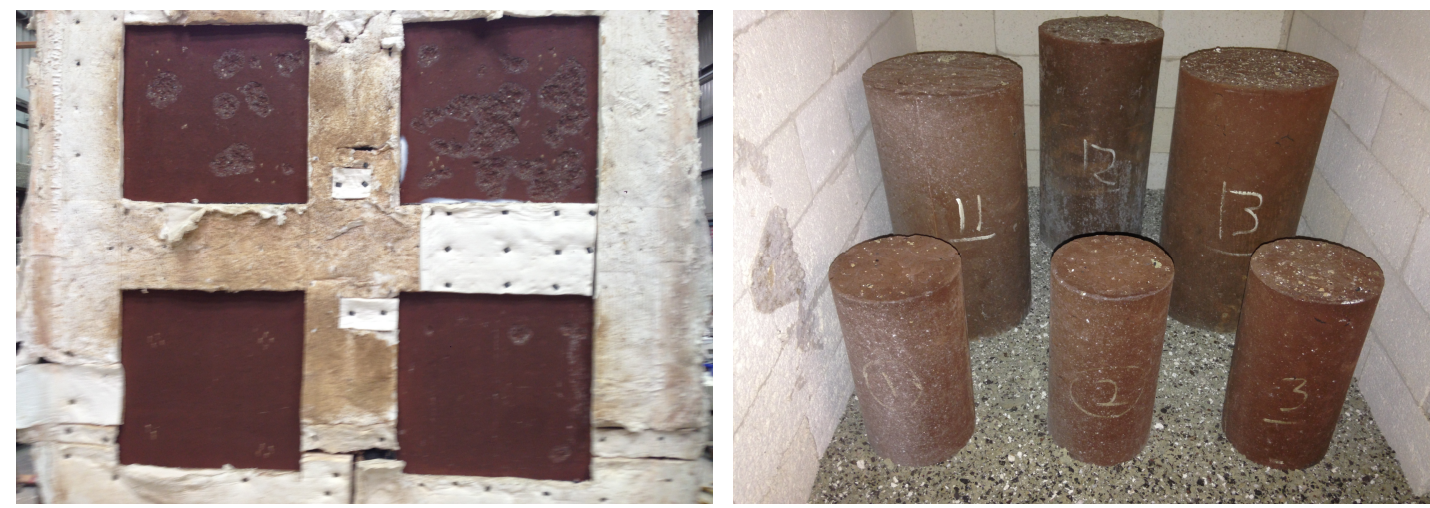

Figure 1. Fire tested Geopolymer concrete specimens.

\subsection{Residual strength}

Geopolymer concrete achieved its strength at very early age. Under curing regime of $60^{\circ} \mathrm{C}$ steam curing for 24 hours, the compressive strength of geopolymer concrete was $54.1 \mathrm{MPa}$. All geopolymer concrete panels and cylinders remained intact after 2 hours of hydrocarbon fire exposure. Therefore, residual compressive strength of geopolymer concrete could be measured. Residual compressive strength of a structure after fire event is an important factor in assessing the safety and integrity of whole structure. The decision for appropriate repair works on structure after fire is based on a reliable assessment of residual strength [14]. Table 2 summarises the average residual compressive strength of geopolymer concrete panel, $150 \mathrm{~mm}$ diameter cylinder and $100 \mathrm{~mm}$ diameter cylinder. From Table 2, it can be seen that geopolymer concrete panel has average residual compressive strength which was the highest $(35.1 \mathrm{MPa})$. Cylinders with $150 \mathrm{~mm}$ diameter and $100 \mathrm{~mm}$ diameter have residual compressive strength of 13.3 and $6.7 \mathrm{MPa}$ respectively. These results show that geopolymer concrete is structurally viable even after fire exposure. The specimen size effect was also exhibited with larger specimen's size showing lesser strength loss due to fire exposure [15].

Table 2. Residual compressive strength summary.

\begin{tabular}{|c|c|c|c|}
\hline \multicolumn{2}{|c|}{ Conrete Type } & \multicolumn{2}{|c|}{$\begin{array}{l}\text { Residual Compreesive Strength } \\
\text { (MPa) }\end{array}$} \\
\hline \multirow{4}{*}{$\begin{array}{c}\text { Panel } \\
\text { (exposed surface) }\end{array}$} & Panel 1 & 38.9 & \multirow{4}{*}{38.5} \\
\hline & Panel 2 & 35.6 & \\
\hline & Panel 3 & 34.3 & \\
\hline & Panel 4 & 45.2 & \\
\hline \multirow{3}{*}{\multicolumn{2}{|c|}{$\begin{array}{c}\text { Cylinder } \\
\text { (150 mm diameter) }\end{array}$}} & 12.1 & \multirow{3}{*}{13.3} \\
\hline & & 14.3 & \\
\hline & & 13.5 & \\
\hline \multirow{3}{*}{\multicolumn{2}{|c|}{$\begin{array}{c}\text { Cylinder } \\
\text { (100 mm diameter) }\end{array}$}} & 7.9 & \multirow{3}{*}{6.7} \\
\hline & & 8.2 & \\
\hline & & 4.1 & \\
\hline
\end{tabular}




\section{Conclusion}

i) There were no explosive spalling observed during the whole length of hydrocarbon fire test on geopolymer specimens. Panel 2 (P2) recorded the highest geopolymer concrete spalling with $4.65 \%$ spalling percentage. However, it is estimated that $3.57 \%-3.75 \%$ of the weight loss was due to the loss of moisture content during fire test. The estimation was based on loss of weight for unspalled panels (P1 and P4). Thus, the spalling percentage of geopolymer concrete was actually less than $1 \%$. There was no spalling observed on geopolymer concrete cylinders even though there were $2.84 \%$ and $2.86 \%$ weight loss for $150 \mathrm{~mm}$ diameter and $100 \mathrm{~mm}$ diameter respectively. The weight loss was due to loss of moisture during fire test.

ii) There was residual compressive strength on geopolymer concrete after hydrocarbon fire test. The fire tested geopolymer concrete panel, $150 \mathrm{~mm}$ diameter cylinder and $100 \mathrm{~mm}$ diameter cylinder have $38.5,13.3$ and $6.7 \mathrm{MPa}$ compressive strength respectively. It proved that geopolymer concrete structurally can withstand load even after being exposed to 2 hours of hydrocarbon fire exposure. It can be concluded that geopolymer concrete is good fire resistant construction material.

\section{References}

[1] F.J. Ulm, P. Acker, and M. Lévy, The "Chunnel" fire. II: Analysis of concrete damage, J. of Engineering Mechanics, 125(3), 283-289, (1999).

[2] J.S. Roh, S.S. Yang, H.S. Ryou, M.O. Yoon and Y.T. Jeong, An experimental study on the effect of ventilation velocity on burning rate in tunnel fires-heptane pool fire case, Building and Environment, 43(7), 1225-1231, (2008).

[3] K.D. Hertz, Limits of spalling of fire-exposed concrete, Fire Safety J., 38(2), 103-116, (2003).

[4] J. Davidovits and M. Davidovics. Geopolymer: Ultra-high temperature tooling material for the manufacture of advanced composites, SAMPE, 2, 1939-1949, (1991).

[5] R.E. Lyon, P.N. Balaguru, A. Foden, U. Sorathia, J. Davidovits and M. Davidovics, Fire-resistant aluminosilicate composites, Fire and Materials, 21(2), 67-73 (1997).

[6] Z. Pan, J.G. Sanjayan and B.V. Rangan, An investigation of the mechanisms for strength gain or loss of geopolymer mortar after exposure to elevated temperature, J. of Materials Science, 44(7), 1873-1880 (2009).

[7] D.L.Y. Kong and J.G. Sanjayan, Damage behavior of geopolymer composites exposed to elevated temperature, Cement and Concrete Composites, 30(10), 986-991(2008).

[8] D.L. Kong, J.G. Sanjayan, and K. Sagoe-Crentsil, Factors affecting the performance of metakaolin geopolymers exposed to elevated temperatures, J. of Materials Science, 43(3), 824-831(2008).

[9] A. Palomo, M.W. Grutzeck, and M.T. Blanco, Alkali-activated fly ashes: A cement for the future, Cement and Concrete Research, 29(8), 1323-1329 (1999).

[10] B.V. Rangan, Fly ash-based geopolymer concrete, Indian Concrete J., 80(2), 35-41, (2006).

[11] IS EN 206:2013, Concrete-Specification, Performance, Production and Conformity, European Committee for Standardization, Brussel, (2013).

[12] D. Hardjito, S.E. Wallah, D.M.J. Sumajouw and B.V. Rangan, On the development of fly ashbased geopolymer concret,. ACI Materials J., 101(6), 467-472, (2004).

[13] BS EN 1991-1-2, Part 1 -2: General Actions-Actions on Structures Exposed to Fire, European Committee for Standardization, Brussels, (2005).

[14] E. Annerel and L. Taerwe. Approaches for the assessment of the residual strength of concrete exposed to fire, Concrete Repair, Rehabilitation and Retrofitting II, Proc. of the 2nd Int. Conf. on Concrete Repair, Rehabilitation and Retrofitting, 245-246, (2009).

[15] M. Li, C. Qian and W. Sun, Mechanical properties of high-strength concrete after fire, Cement and Concrete Research, 34(6), 1001-1005, (2004). 